\section{UP-257 再燃前立腺癌に対するビカルタミドの効果}

\section{東京大学 泌尿器科 1}

中 朗”玉城 吉得" 武内 巧”太田 信隆”筫和田 滋" 北村 唯一"

【目的】再燃前立腺癌に対して現在のとこ万有効な治療法は確立 されていない。今回我々は再然前立腺癌に対するビカルタミドの 効果について检討した。【対象および方法】内分泌療法後に再燃 を認め、ビカルタミド $(80 \mathrm{mg} / \mathrm{day})$ を含めた内分泌㙩法を施行 した前立腺癌28例(平均74.5歳)を対象とした。臨床病期は、Stage C 9例、Stage D1 3例、Stage D2 16例で、病理組織は、高分化 型腺涾3例、中分化型13例、低分化型12例であった。先行する内 分泌療法は、アンドロゲン除去単独4例、アンドロゲン除去十抗 アンドロゲン剂8例、アンドロゲン除去十抗アンドロゲン剤エエ ストロゲン剤例、アンドロゲン除去十エストロゲン剤7例であっ た。また4例に前立腺全摘除術、5例に化学療法、2例に放射線療 法む施行された。効果判定は、PSAの $80 \%$ 以上の改善を著効、50 $\%$ 以上 $80 \%$ 未満の改善を有効、それ以外を無効とした。【結果】 28例中、著効 5 例、有効 5 例、無効18例であった。有効率は $36 \%$ (28例中 10例)、有効例の nadir 到達平均期間は60日、有効期間 （中央値）は214日以上であった。【結語】再燃前立腺癌に対して ビカルタミド投与は有効であった。，先行する抗アンドロゲン郕、 エストロゲン剤投与の有無は、ビカルタミドの有効率に影響を与 えなかった。

前立腺癌 ビカルタミド

\section{UP-259 前立腺癌に対する内分泌療法に起因する hot flushーホルモン環境からの検討}

\section{東部地域病院 泌尿器科1)}

安藤 正大”遠坂 顕" 川野明子" 有澤 千鶴"

【目的】前立腺癌に対する内分泌療法では、突然の体のほてりや 発汗など、いわゆる hot flush(HF)を呈する症例がある。内分泌 療法により何故HFが起こるのか、ホルモン環境からの解明を試 みた。【対象・方法】当科で内分泌療法を施行した75例の前立腺 癌患者を対象とした。年㱓は49〜86歳 (平均71歳)で、臨床病期 は $\mathrm{A}_{2} 4$ 例、B22例、C20例、D29例。方法はアンケート用紙およ び問診でHFの有無・程度を確認し、同時に血中LH、FSH、テス トステロン（T）、エストラジオール（E2）およびプロラクチン （PRL）を測定した。【結果】75例中HFのある患者48例、HFの ない患者27例にホルモン採血を施行した。内分泌燎法の内訳は、 去勢術単独 (1群) 24例、去勢術とフルタミド（F）あるいはビ力 ルタミド（B）併用（2群）21例、LHRHアゴニスト（LHRH） 単独（3群）13例、LHRHとFあるいはB併用（4群）10例、女性 ホルモン他併用（5群）7例であった。1〜5群ともTの著明な低 下、E2低下およびPRLの正常ないし軽度上昇を認めた。1・2群 ではLH・FSHの上昇を、3・4群ではLH低下、正常FSH值を認め た。1〜4群ともHFの有無別でのホルモン環境の差は認めなかっ た。5群では全例HFはなく、LH、FSHとも低下している例が多 かった。【結語】血中T、E2、LH、FSH、PRLには、HFの有無 別の差は認められなかった。

前立腺癌 内分泌療法 hot flush

\section{UP-258 前立腺癌再燃症例における anti-androgen 鼡} の変更の索果

\section{産業医科大学 医学部 泌尿器科 ${ }^{11}$}

\author{
原田 修治" 藤本 直浩" 高橋 康一"松本 哲朗"
}

[目的］前立腺癌の治療において、ホルモン療法中に再燃をきた した症例において、anti-androgenの变更を試み、その有用性につ いて検討した。[対象と方法］StageCおよびD2の前立腺癌患者で、 LH-RH analogue (Leuprorelin3.75mg/4w) およびflutamide 375 $\mathrm{mg} /$ dayによるmaximum androgen blockade (MAB)を施行中、 再燃をきたした症例12例に対し、anati-androgen withdrawal syndrome(AWS)を観察したのちbicalutamide $80 \mathrm{mg} /$ dayの投与を試 み、その効果を検討した。[結果] flutamide投与中の再燃例で AWSがない8例において、bicalutamideは6例で無効だが、2例は有 効であった。AWSがみられた症例において、その後の再燃時の bicalutamide投与は有効であった。また、肝機能障害のためflutamide を中止した症例で、LH-RH analogue単独療法中の再燃4例では、 1例は酶酸クロルマジノン (CMA) 無効でbicalutamide有効、2例は bicalutamide有効、1例は無効であった。[結論］flutamide投与中 のAWS例ではbicalutamideは著効した。AWSがみられない場合で あbicalutamideが有効である症例が存在し、 second lineのホルモ ン療法としてanti-androgenの変更は試みるべきであると考えられ た。

前立腺癌 再燃 anti-androgen
未治療前立腺癌症例に対するLH-RH agonist投与時 のflare up予防效果; diethylstilbestrol diphosphate, Estracyt, chlormadinone acetate による比較検討

\section{群馬大学 医学部 泌尿器科"}

松井博" 鈴木 和浩" 中里 晴樹 ${ }^{12}$ 蓮見 勝" 柴田 康博 伊藤 一人'深堀 能立 ${ }^{1}$ 黑川公平 " 山中 英壽"

【目的】未治療前立腺癌のLH-RH agonist投与に伴うflare upに 対 $、$ diethylstilbestrol diphsphate (DES-DP), Estracyte (ECT), chlormadinone acetate(CMA)による予防効果について検討した。 【対象上万法】1997年から1999年に群馬大学医学部附属病院泌尿 器科で加療した未治療前立腺癌の15例を対象とした。DES-DP $125 \mathrm{mg} /$ dayを21日点滴静注した群、ECT $560 \mathrm{mg} /$ dayを21日 経口投与した群、CMA $100 \mathrm{mg} /$ dayを28日経口投与した群に 分け、下垂体一精单系のホルモンおよびPSA值を測定し比較検討 した。LH-RH agonistは14日目に投与した。【結果】Testosterone 值 (T) はDES-DP,ECT群では投与開始 2 週後には著明に抑制さ れ0.2 ng/ml以下となったが、CMAでは0.7 ng/mlであった。 いずれの群もLH-RH agonist投与後3日目に一過性の上昇を認め た。LH, FSHは3群とも同様の変動を示し、LH-RH agonist投与 後1日目に著明な上昇を認めたが、2日後には投与前と同レベルに 低下した。PSA值はいずれの群であ速やかに低下し、経過中に上 昇を認めなかった。【結論】未治療前立腺癌症例に対する初回 LH-RH agonist投与に対するflare up予防は、T值の抑制について はCMAで効果がやや弱いものの、いずれの薬剤もPSAの再上昇 および症状の增悪を認めず、有効であった。

前立腺癌 flare up LH-RH agonist 